\title{
A Story of 'Trials and Errors' That Might Have No Happy End
}

\author{
Jörg Luther†
}

\begin{abstract}
The International Court of Justice (ICJ) and Italian Constitutional Court (ItCC) have created a deadlock between two diverging res iudicatae on state immunities and judicial remedies as well as a tension between two republics that do not share the same constitutional and international identities. In order to avoid a further spiralling of decisions, judges tried to promote the negotiation of 'a happy outcome' for a category of victims of war crimes that risk dying without being entitled to any compensation. This chapter analyses the general cultural context of 'academic diplomacy'. Both state sovereignty and human solidarity could be maintained through a voluntary compensation for moral damages to the victims of massacres, deportation, and forced labour during World War II. The moralresponsibility approach suggested by the ICJ could be stronger than the legalliability threat backed by the ItCC. A belated common solidarity funded by both German and Italian citizens and employers could be the best way out, but considering that many of the now elderly victims are approaching the end of their lifespans, it might be cynically too late. This could, paradoxically, help to remind the world of the injustices they suffered. Yet, on grounds of this tragic end, state immunity and fundamental rights might further be delegitimized in possible wars to come.
\end{abstract}

\section{The Complexity of the Reconciliation Task}

The bilateral and worldwide discussion on the Jurisdictional Immunities Judgment of the International Court of Justice (ICJ) ${ }^{1}$ and the Italian Constitutional Court's (ItCC) Judgment $238 / 2014^{2}$ on the right to a remedy has been conducted from

Jörg Luther was a Professor of Public Law in the Department of Law and Political Sciences, Economics and Social Sciences at the University of Eastern Piedmont Amedeo Avogadro in Alessandria, Italy. He passed away while this chapter was under revision, and Giovanni Boggero and Valentina Volpe helped to finalize it.

${ }^{1}$ ICJ, Jurisdictional Immunities of the State (Germany v Italy: Greece intervening), Judgment of 3 February 2012, ICJ Reports 2012, 99.

${ }^{2}$ Corte Costituzionale, Judgment of 22 October 2014, No 238/2014. 
different viewpoints. The facts and norms in question are the object of various legal, moral and political interests that include the victims and their heirs, the culprits, as well as involved nation-states and domestic and international institutions. The different views on German and Italian legal orders focus just on the reconciliation between the two states, but the questions involved are potentially of interest also to the former Allied Forces as well as to countries like Austria, Greece, Poland and Israel. Furthermore, the 'remedies against immunity' quandary involves the whole international legal and political order, itself shaped by a highly dynamic multilevel governance structure. All these views need a more comprehensive reconciliation that has to be carried out in different places and under different and changing legal and political conditions.

The reconciliation of colliding international and domestic laws, however, has to reckon with the specific case: the evident historical atrocities and injustices of a dreadful 'past that will not pass' ${ }^{3}$ The ICJ assigned a victory to Germany that might have been as such accepted by the Italian government, but it could not reconcile the two states with their history nor foster a shared understanding of what human dignity should mean for the future. The ItCC made an appeal to human dignity and in the name of the Italian people decided in favour of human rights protection against Germany and against those immunities that within the constitutional state have been increasingly restricted — though not abolished—over the last decades.

The decisions of international judges as defenders of sovereign state immunity and of national constitutional court judges as defenders of fundamental rights protection created a legal deadlock and have somewhat benighted diplomatic relations between Italy and Germany. In a context of amplified national passions, domestic views on the development of international law and on 'constitutional identities' appear to be diverging, if not clashing. On the one hand Germany prefers to shield behind its sovereignty to close the books on the past, looking forward to friendly relations, while supporting state immunity. On the other hand, Italy commits to an international order based on 'peace and justice' (Article 11 of the Italian Constitution) demanding the rights protection of still living victims of that 'past that will not pass'. The task of reconciliation is still in need of improvement, something different from an acquis of diplomacy that could be self-certified by governments.

The follow-up of both judgments makes this task still uncertain in its outcome. On the one hand there is an international res iudicata, formally opposed by Sentenza 238/2014, that invalidated both the specific provision of Article 3 of Italian Law No $5 / 2013$ made for the execution of the ICJ Judgment and the part of Italian Law No 848/1957 implementing the UN Charter. ${ }^{4}$ Germany might address the UN Security

\footnotetext{
${ }^{3}$ Ernst Nolte, 'Vergangenheit die nicht vergehen will', Frankfurter Allgemeine Zeitung (5 June 1986).

${ }^{4}$ This point 'concerns the execution of Article 94 of the United Nations Charter, exclusively to the extent that it obliges the Italian judge to comply with the Judgment of the ICJ of 3 February 2012, which requires that Italian courts deny their jurisdiction in case of acts of a foreign state constituting war crimes and crimes against humanity, in breach of inviolable human rights.' ItCC, Judgment 238/2014 (n 2), para 1.1.
} 
Council under Article 94(2) of the UN Charter, present a new complaint to the ICJ for a violation of state immunity and appeal, under Article 39 of the European Convention for the Peaceful Settlement of Disputes of 29 April 1957, to the Committee of Ministers of the Council of Europe, and get a two-thirds majority for issuing 'recommendations with a view to ensuring compliance with the (...) decision'. In any case, the Italian government should reserve part of its budget for mitigating the consequences of the execution of Italian judgments against Germany.

On the other hand, Judgment 238/2014 has a specific constitutional res iudicata: ${ }^{5}$ Article 136 and Article 137(3) of the Italian Constitution prescribe that the law declared unconstitutional 'ceases to have effect from the day following the publication of the decision' and no appeal can be allowed. The constitutional res iudicata applies also to the implicit declaration of the unconstitutionality of the international customary law norm. ${ }^{6}$ Furthermore, it applies to the order to give execution to the ICJ Judgment implied in the legal authorization to ratify Article 96 of the UN Charter, and the ItCC did not restrict the decision to the first section. The implementation of decisions of international bodies aiming to reproduce the same norm that ceased to have effect would violate Article 137(3) of the Italian Constitution and could be rendered ineffective by a further ItCC judgement.

This describes the deadlock created by both decisions. However, they might not be the judges' last words, and lawmakers could try to renegotiate the treaties or amend the Constitution. ${ }^{7}$ The ICJ Judgment could be not the first one to be disregarded, but Sentenza risks in turn to have a merely symbolic value. On the one hand, the ICJ Judgment's lack of implementation could be the beginning of the end of the customary law norm. If third-party judges were to join the Italian position, customs could change over time. On the other hand, as the ItCC judgement allowed only a declaratory relief in the Italian courts, the 'victorious' victims could not get any of the Italian courts' judgments enforced against the Federal Republic of Germany unless a further declaration of unconstitutionality of the international and national laws that still grant immunity from execution comes about. ${ }^{8}$ The lack of effective justice for the victims and the impact on international customary law could affect the judgment in a regrettable way.

In any case, the deadlock could be a tragedy. More than for the judges or for the respective German and Italian states, this is true for those who still have hope in receiving justice. These victims invested money in costly legal proceedings, but judges could issue only symbolic, not enforceable, decisions.

\footnotetext{
${ }^{5}$ See Francesco Dal Canto, Il giudicato costituzionale nel giudizio sulle leggi (Turin: Giappichelli 2002), 30 et seq.

${ }^{6}$ See the final judgments of the Tribunale di Firenze in the aftermath of Sentenza 238/2014, discussed by Paolo Veronesi, Colpe di stato (Milan: Franco Angeli 2017), 228 et seq.

${ }^{7}$ Stefan Rinke, Schadensersatzklagen gegen Staaten wegen schwerer Menschenrechtsverletzungen im europäischen Zivilprozessrecht (Berlin: Berliner Wissenschafts-Verlag 2017).

${ }^{8}$ See also Paolo Palchetti, chapter 'Right of Access to (Italian) Courts über alles?', in this volume.
} 
The culture of memory matters for this reconciliation and the costs of this culture may exceed the investment done so far, which emphasized monuments building and the work of historians. In a first step, this chapter focuses on the general context of 'academic diplomacy' after Sentenza 238/2014 (section II). In a second step, the common concerns for the rights of victims of war crimes and forced labour need to be addressed, reasoning on the opportunities and risks of a 'belated' solidarity solution (sections III-V). In a third step, some conclusions for the proper use of 'constitutional identities' in the context of international relations will be drawn (sections VI-VII).

\section{Academic Diplomacy as a Supplement to Governmental and Judicial Dialogues}

Academic diplomacy is a new concept in peace studies and offers a means for sustainable reconciliation. Academic culture could represent nations and become a path finder for solutions to a deadlock created by governments and judges. Academic legal culture could move beyond its role as adnotatores of conflicting decisions towards a constructive and friendly cross-border dialogue based on a search for comparative constitutional and international law solutions. But diplomacy is more a political than a legal discourse and law professors generally lack sufficient information regarding ongoing diplomatic dialogue and negotiations.

What is well known concerning the case at hand is that several scholars have already been involved through expert opinions pro veritate, advocating for governments and parliaments; others might have an interest in pursuing an international career in the judiciary. Present-day institutions fostering international academic dialogue, including the German-Italian Constitutional Colloquium (DeutschItalienisches Verfassungskolloquium), have been less engaged in currently disputed topics. The forerunner of the concept of academic diplomacy was the GermanItalian Commission of Historians (Historikerkommission, 2009-2012). ${ }^{9}$ Its political mandate prudently kept out all legal questions as well as the participation of legal historians in order not to encroach upon the work of the ICJ. ${ }^{10}$ The participating

\footnotetext{
${ }^{9}$ 'Bericht der von den Außenministern der Bundesrepublik Deutschland und der Italienischen Republik am 28.3.2009 eingesetzten Deutsch-Italienischen Historikerkommission', (July 2012), available at http://www.villavigoni.it/contents/files/Abschlussbericht.pdf, 1-180, at 45: 'Military internees cannot disappear longer from history and end up in the grey area of Italian and German memory; rather the remembrance of their innocent fate should symbolically unite Germans and Italians'; (translated by the author).

${ }^{10}$ Guido Westerwelle (former German Minister of Foreign Affairs), 'Ansprache von Außenminister Westerwelle anlässlich der Übergabe des Abschlussberichts der Deutsch-Italienischen Historikerkommission in Rom', (19 December 2012), available at www.auswaertiges-amt.de/DE/ Infoservice/Presse/Reden/2012/121219-BM_Rom.html?nn=360110: 'In the name of Germany, unjustifiable crimes were committed in Italy and against Italians in the years 1943-1945. These crimes cannot be relativized through historical differentiation either. Also, the proceedings before
} 
historians were obliged to ignore the legal questions and their attendant tensions because the governments preferred that a cultural consensus could render the legal dispute resolution sustainable. The Foreign Ministers of the governments of Angela Merkel and Silvio Berlusconi agreed to pay for the work of historians but not to pay compensation to the victims of this history and excluded any consideration of this question from the mandate of the German-Italian Commission. A number of historians complained, feeling that they were used by statesmen engaged in a larger political game. In unhappy times of financial crisis, diplomacy and political prudence led to the conclusion that 'making history with money' was better than 'making money with history'. In the end, those historians agreed that both further historical research and memorial monuments should be financed. Domestic and international judges had to enter into the scene to finally raise the issue of the rights of victims.

Academic diplomacy is now required to help reconcile a deadlock that seems to be the result of a lack of direct judicial dialogue. Transnational judicial dialogues are already well developed among constitutional judges and within international associations of judges, but there seems to be little dialogue between supreme courts. After World War II (WWII), as far as the German and Italian judiciary are concerned, a sort of a silent convention and a common interest to slow down criminal justice for war-related crimes emerged, preventing any real cooperation for an efficient prosecution.

Some of the tensions from the recent legal quarrels on the rights of victims need to be remembered.

The ItCC decided already in the Priebke case (1996) to strike down a norm of the military criminal procedure Act that excluded civilians from claiming war-crimesrelated damages in military courts. ${ }^{11}$

In the same year, the German Bundesverfassungsgericht decided that individual claims for the years 1943-1945 were to be based not on international, but on domestic law. ${ }^{12}$

The German Bundesgerichtshof decided then in the Distomo case (2003) that victims of military actions abroad were not entitled to any individual compensation, a principle that has been further developed in the more recent Kunduz case (2016). ${ }^{13}$

\footnotetext{
the International Court of Justice, which lastly created legal certainty with its judgment on the important issue of state immunity of 3 February [2012], never pursued the goal of putting German responsibility for these crimes into question. Legal issues and historical responsibility must be strictly separated the one from the other'; (translated by the author).

${ }^{11}$ Corte Costituzionale, Judgment of 28 February 1996, No 60/1996.

${ }^{12}$ Bundesverfassungsgericht, Order of 13 May 1996, 2 BvL 33/93, BVerfGE 94, 315 (Zwangsarbeit), 329 et seq.

${ }^{13}$ Bundesgerichtshof, Judgment of 26 June 2003, III ZR 245/98, BGHZ 155, 279 (Distomo); Bundesgerichtshof, Judgment of 6 October 2016, III ZR 140/15, BGHZ (Kunduz).
} 
The Italian Corte di Cassazione decided in the Ferrini case (2004) that the Federal Republic of Germany had to pay damages to citizens who were deported and coerced into forced labour camps from the Italian territory. ${ }^{14}$

The Bundesverfassungsgericht 'answered' in the same year that the right of inhabitants from an occupied territory to get international humanitarian law enforced does not include directly enforceable individual claims to compensation. All claims for compensation concerning torts and unlawful enrichment related to forced labour could be protected, if not prescribed, only as property rights. ${ }^{15}$

Between 2008 and 2011, the Corte di Cassazione allowed the enforcement of the Greek Distomo judgment and held Germany liable for massacres perpetrated during WWII. Immunity has been further weakened by allowing war-crimes-related trials even upon claims originating from municipalities and the National Association of Italian Partisans (Associazione Nazionale Partigiani Italiani, ANPI) (2014). ${ }^{16}$

These judicial dynamics show cultural differences and inner conflicts between the two legal orders with a clear lack of a real dialogue. As a matter of fact, judicial decisions and legal opinions adopted in one country rarely quote the judicial decisions and legal opinions adopted in the other. The courts of Strasbourg and Luxembourg, in turn, did not offer any common ground and even the Goethe Institute and the Dante Alighieri Society never tried to promote academic diplomacy.

Nevertheless, the absence of judicial dialogue was not offset by national governments' intervention. The Italian government did not intervene in German court proceedings and, symmetrically, the German government did not intervene in the proceeding before the ItCC. They agreed in the ICJ proceedings that Villa Vigoni needed immunity from execution. The implementation of both the ICJ Judgment and Sentenza 238/2014 was the object of further diplomatic dialogue, but this topic was left out from any discussion during the Italian-German High-Level Dialogue of the two Heads of State held in Turin in 2014 and again in 2016. ${ }^{17}$

The Foreign Ministers preferred silent diplomacy: they signed agreements with the ANPI and the National Association of Survivors of Imprisonment, Internment and the War of Liberation (Associazione Nazionale Reduci dalla Prigionia,

\footnotetext{
${ }^{14}$ Corte di Cassazione, Judgment of 11 March 2004, No 5044/2004.

${ }^{15}$ Bundesverfassungsgericht, Order of 7 December 2004, 1 BvR 1804/03, BVerfGE 112, 93; Bundesverfassungsgericht, Order of 28 June 2004, 2 BvR 1379/01, BVerfGK 3, 277.

${ }^{16}$ Corte di Cassazione, Judgment of 29 May 2008, No 14199/2008; Corte di Cassazione, Orders of 29 May 2008, No 14200-14212/2008; Corte di Cassazione, Judgment of 21 October 2008, No 1072/2008 (Milde); Corte di Cassazione, Judgment of 19 March 2014, No 329/2014: '[T]his association was born, according to its statute, with the aim of continuing the work of partisan groups, embodying their history and tradition; therefore, it should be acknowledged the right to compensation for the crimes which directly touched upon partisan groups'; (translated by the author).

${ }^{17}$ Bundespräsident, 'Opening of the Italian-German High-Level Dialogue', (11 December 2014), available at http://www.bundespraesident.de/SharedDocs/Reden/EN/JoachimGauck/Reden/2014/ 141211-Italienisch-Deutsches-Dialogforum.html; Quirinale, 'Intervento del Presidente della Repubblica, Sergio Mattarella, al Dialogo di Alto Livello italo-tedesco', (13 April 2016), available at http://www.quirinale.it/elementi/1130.
} 
dall'Internamento, dalla Guerra di Liberazione, ANRP) and set up a German-Italian Fund (deutsch-italienischer Zukunftsfond) within the German Federal Foreign Office. ${ }^{18}$ The strategy of symbolic reparation supported by historians was further developed through a temporary exhibition in Berlin.

Parliamentary diplomacy, especially within the German-Italian parliamentary group and within the European Parliament, could make further efforts towards reconciliation. The majority-approved motion of the Italian parliament demanded only the execution of the Italian judgments relating to the massacres perpetrated by German forces, excluding therefore compensation for Italian Military Internees (IMIs). The latter's interests have been defended and represented by more Eurosceptic political parties like the Lega Nord in Italy or Die Linke in Germany. ${ }^{19}$

In the context of existing governmental dialogue, the concerns of Germany and Italy are only partially conflicting. One could even conclude that a possible common German-Italian viewpoint could be to pay no compensation at all, and academic diplomacy should just sustain this 'gentle nations' agreement' ${ }^{20}$ The German government recognizes a moral rather than a legal responsibility towards individuals; this position vis-à-vis the victims could be summed up in the motto: 'memory, not money'. Following this spirit, the Italian parliament recognized already through the enactment of Law No 269/2006 that the sacrifice made by the Italian victims of deportation deserves a medal of honour 'as compensation mainly for the moral damages'. 21

\footnotetext{
${ }^{18}$ Die Linke, 'Kleine Anfrage: Arbeitsweise und Förderkriterien des deutsch-italienischen Zukunftsfonds', (4 March 2016), available at http://dip21.bundestag.de/dip21/btd/18/077/ 1807799.pdf.

${ }^{19}$ For Italy, Camera dei deputati, 'XVII Legislatura-Resoconto stenografico dell'Assemblea Seduta n 711 di martedì 6 dicembre 2016', (6 December 2016), available at http://www.camera. it/leg17/410?idSeduta=0711\&tipo=stenografico. For Germany, Federal Government, 'Antwort der Bundesregierung auf die Kleine Anfrage der Abgeordneten Ulla Jelpke, Jan Korte, Sevim Dagdelen, weiterer Abgeordneter und der Fraktion Die Linke-Drucksache 18/3333 Entschädigung für NS-Opfer in Italien', (9 December 2014), available at http://dip21.bundestag. de/dip21/btd/18/034/1803492.pdf.

${ }^{20} \mathrm{Cf}$ Franco Frattini, Italian Minister of Foreign Affairs at the time, 'Wir brauchen eine symbolische Geste', Süddeutsche Zeitung (17 May 2010): 'These people have suffered. If we give them 3,000 euros now, it is not what they need (...) I think a symbolic gesture, such as a memorial or a museum of remembrance that Germany and Italy can set up together would be much more important'; (translated by the author).

${ }^{21}$ Cf Italian Law 24 October 2006, No 269, Art 1, paras 1271-1272, (translated by the author).

1271. The Italian Republic recognizes the sacrifice of its citizens deported and interned in Nazi concentration camps in the last world conflict by entitling them to a compensation, mostly of moral nature.

1272. It has been authorized the granting of a medal of honour to Italian citizens, both military and civilians, deported and interned in Nazi concentration camps and destined to forced labour for the sake of war economy, to whom, if military, has been denied by the then Nazi government the status of prisoners of war, according to the Convention relative to the treatment of prisoners of war made in Geneva on 27 July 1929, and to the families of those who have died, who are entitled to present the application for recognition of the status of forced labourer.
} 
However, academic diplomacy's supporters could express some doubts: can states 'wash their hands' from their responsibility and limit it to monuments and medals? Is the decision to provide no financial compensation for the moral and existential damages really the best way for closing this particular historical chapter? Is it just hyper-moralism and hyper-idealism to propose a symbolic financial recognition, three decades after the fall of the Berlin Wall, as a sign of Europe's confidence in the future of an EU based on the respect of human rights, justice and solidarity (Article 2 TEU)?

In a very drastic and exaggerated way one could read the conflict assessed by the ICJ Judgment and Sentenza 238/2014 as a theatre of 'cynicism and hypocrisy'. The real conflict is not just between Germany and Italy, nations which sometimes consider themselves as being each other's victims. Instead, it is a conflict between the governments of two former belligerent states and their victims in the context of individual compensation for war crimes and forced labour. Moreover, it is a clash between humanitarian ideals and populist realities in the funding of welfare. If human and humanitarian concerns are paramount common concerns for all constitutional states in the EU and for the international community at large, the response of Germany and Italy could be to reconsider the issue of compensation for the victims of massacres, deportation, and forced labour. In this context, academic diplomacy would not just be a form of state-centred government support but an independent diplomatic action for a transnational civil society.

\section{Moral Responsibility and Legal Liability}

Are Germany and Italy obliged to open negotiations and settle the dispute? If we look at both the ICJ Judgment and Sentenza 238/2014 merely from a formal legal point of view, the answer would be 'no'. However, if we consider lifelong solidarity towards the victims as a moral duty and we refrain from the idea of having purely 'moral' or 'memory' politics then the answer could be 'yes'. 22

The ICJ Judgment as interpreted by the ItCC pointed out that the opening of new negotiations might be the only means available to settle the dispute in international law. ${ }^{23}$ The ICJ made a very strong moral obiter dictum that seems to have been neglected by the public debates: 'The Court considers that it is a matter of surpriseand regret - that Germany decided to deny compensation to a group of victims on the ground that they had been entitled to a status which, at the relevant time,

\footnotetext{
${ }^{22}$ Hanne Leßau, Conference Report, 'Entschädigung als Menschenrecht? Theorie und Praxis des Umgangs mit den Opfern kollektiver Gewalt', organizer Constantin Goschler, in H-Soz-Kult (16 October 2012), available at http://www.hsozkult.de/conferencereport/id/tagungsberichte4412 >. Cf Andreas von Arnauld, chapter 'Deadlocked in Dualism', in this volume.

${ }^{23}$ ICJ, Jurisdictional Immunities (n 1), para 104.
} 
Germany had refused to recognize, particularly since those victims had thereby been denied the legal protection to which that status entitled them. ${ }^{24}$

The 'surprise' relates to an ex post recognition of protection duties for the only purpose of denying compensation. Adolf Hitler's order of 20 September 1943 commanded the deportation to the German Reich of the captured Italian Military Internees (IMIs) as forced labour force for the production of arms and for the construction of the so called 'South-East Wall'. ${ }^{25}$ This was a deliberate violation of Article 31 of the Geneva Convention on the Treatment of Prisoners of War of 1929: 'Work done by prisoners of war shall have no direct connection with the operations of the war. In particular, it is forbidden to employ prisoners in the manufacture or transport of arms or munitions of any kind, or on the transport of material destined for combatant units. ${ }^{26}$ Furthermore, contrary to international humanitarian law, any assistance from the Red Cross was denied and fundamental social rights to adequate food and health services were violated. ${ }^{27}$ The IMIs were mishandled and treated as traitors by both German military forces and German civilians as well as by Italian fascists. Most of the captured did not actively resist, and a large number was subjected to forced 'conscription' by German troops. When the workers in what was then the occupied northern-Italian territory went on strike, Joachim Ribbentrop ordered the leaders to be killed as 'communists' and, with an eye towards deterrence, ordered that other thousands be deported as 'IMIs'. ${ }^{28}$ When Hitler decided to transform their status into a sort of fictitious 'private' labour force, a concession to both Fritz Sauckel ${ }^{29}$ and Benito Mussolini's non-sovereign Republic of Salò, they lost their status as military personnel under Italian law and were considered not victims of slavery under Article 600 of the Italian Criminal Code but 'collaborationists'. At the end of the war, the Allied Forces qualified them as 'ex allied of the enemy', with the consequence that their return to Italy was delayed. Their ex post recognition as war prisoners came first from the Italian Republic (1945) — with regard to the period from 8 September 1943 to 1 September 1944and later by Germany (2001) with regard to the remaining periods, even though the

\footnotetext{
${ }^{24}$ Ibid, para 99.

${ }^{25} \mathrm{Cf}$ Keitel Order quoted in Christian Tomuschat, 'Leistungsberechtigung der Italienischen Militärinternierten nach dem Gesetz zur Errichtung einer Stiftung "Erinnerung, Verantwortung und Zukunft"? - Rechtsgutachten' (2001), available at http://www.berliner-geschichtswerkstatt.de/ zwangsarbeit/imi/imi-tomuschat-gutachten.pdf, 1-37, at 2. See Jean Allain, Slavery in International Law-Of Human Exploitation and Trafficking (Leiden: Brill, Nijhoff 2012), 261.

${ }^{26}$ Art 31 of the Geneva Convention relative to the Treatment of Prisoners of War, 27 July 1929, 47 Stat 2021, TS No 846.

${ }^{27}$ See 'Bericht der Deutsch-Italienischen Historikerkommission' 2012 (n 9), 133.

${ }^{28}$ Joachim Ribbentrop to German Embassy, December 1944, quoted in Erich Kuby, Verrat auf Deutsch-Wie das Dritte Reich Italien ruinierte (Frankfurt: Ullstein Sachbuch 1987), 449.

${ }^{29}$ The official reconstruction of the commission of historians on the IMIs seems to be not yet sufficient, neither on the legal qualifications nor on the facts-for example regarding the forced conscription to military service and labour pushed by Sauckel. See Ulrich Herbert, Hitler's Foreign Workers: Enforced Labor in Germany under the Third Reich (Cambridge: CUP 1997), 286.
} 
recognition was exclusively for the purpose of excluding them from any social benefits.

The ICJ's 'regret' implies a clear moral condemnation of both the deportation of IMIs to forced labour camps and their lack of compensation thereof. This neither includes nor excludes a legal qualification as war crime, a violation of ius cogens, or a duty to individual compensation. The judges sitting in the ICJ did not only express their own personal concern, they also tried to embody those common human values shared by all civilized nations by adding a second obiter dictum:

[T] he Court is not unaware that the immunity from jurisdiction of Germany in accordance with international law may preclude judicial redress for the Italian nationals concerned. It considers however that the claims arising from the treatment of the Italian military internees referred to in paragraph 99, together with other claims of Italian nationals which have allegedly not been settled — and which formed the basis for the Italian proceedings — could be the subject of further negotiation involving the two states concerned, with a view to resolving the issue. ${ }^{30}$

The ICJ opted for 'could be' because 'should be' would have been seen as a declaration ultra vires, considering that its Order of 6 July 2010 had already declared inadmissible a counterclaim presented by Italy regarding the reparation owed to Italian victims of grave violations of international humanitarian law committed by the armed forces of the German Reich. The ICJ could not condemn Germany to 'offer appropriate and effective reparation to these victims, by means of its own choosing, as well as through the conclusion of agreements with Italy'. 31

Nevertheless, the clear moral condemnation in paragraph 99 of the ICJ Judgment could, in the long run, prove to be even stronger than a formal legal condemnation. Germany's book of legal debts may well be closed, the book of moral responsibility, however, could remain open-ended.

\section{The Imperfect Lump Sum Agreements of 1961}

When taking into consideration exemptions from state immunity, the ICJ mentions the lump sum agreements and Germany's strongest prima facie objection:

Moreover, if a lump sum settlement has been made-which has been the normal practice in the aftermath of war, as Italy recognizes - then the determination of whether a particular claimant continued to have an entitlement to compensation would entail an investigation by the court of the details of that settlement and the manner in which the State which had received funds (in this case the State in which the court in question is located) has distributed those funds. Where the State receiving funds as part of what was intended as a comprehensive settlement in the aftermath of an armed conflict has elected to use those funds to rebuild

\footnotetext{
${ }^{30} \mathrm{ICJ}$, Jurisdictional Immunities (n 1), para 104.

${ }^{31}$ ICJ, Jurisdictional Immunities of the State (Germany v Italy), Counter-Claim, Order of 6 July 2010, ICJ Reports 2010, 310, para 3.
} 
its national economy and infrastructure, rather than distributing them to individual victims amongst its nationals, it is difficult to see why the fact that those individuals had not received a share in the money should be a reason for entitling them to claim against the State that had transferred money to their State of nationality. ${ }^{32}$

From the opposite Italian point of view, the 'questions settled through the 1961 Agreements were (...) limited to, on the one hand, the pending economic questions to be identified merely as those covered by the 1947 waiver clause, and, on the other, compensation to victims of National Socialist persecution'. That implied three objections: first, the waiver of Article 77(4) of the Peace Treaty of $1947^{33}$ was not approved by Germany under Article 34 or 36 of the Vienna Convention of 1969 and was referred only to property-related questions, not to labour-based claims; second, the agreements of 1961 concerned only the most important 'specific claims, ${ }^{34}$ not all the reparations delayed to a final examination under Article 5(2) of the London Debt Agreement of $1953 ;{ }^{35}$ and third, the civilian massacres, deportation, and forced labour were not specific National Socialist persecutions covered by the agreements.

Regarding the first reply, the Italian interpretation has been outlined by the former judge of the Italian Constitutional Court Rita Saulle ${ }^{36}$ and has been adopted by the Italian Corte di Cassazione and ordinary judges since $2008 .{ }^{37}$ It has to be added that the Constituent Assembly authorized the ratification of the Peace Treaty of 1947, adopting a resolution that declared the punitive reparations of the treaty as incompatible with the principles of international justice and thus demanded their revision. The Minister of Foreign Affairs, Carlo Sforza, declared that Germany was obliged to provide for reparations and to give adequate guarantees but the country should not be excluded from a future European Community. ${ }^{38}$ The original Italian intent was thus not at all to accept a full and binding waiver for any future reparation claim.

As for the second objection, Article 2 of the 1961 Agreement on the Settlement of Certain Property-Related, Economic and Financial Questions established a waiver for 'all outstanding claims'. The 1961 Agreement on the Compensation for Italian

\footnotetext{
${ }^{32} \mathrm{ICJ}$, Jurisdictional Immunities (n 1), para 102.

${ }^{33}$ Treaty of Peace with Italy, 10 February 1947, 49 UNTS 3.

${ }^{34}$ Agreement between the Federal Republic of Germany and Italy on the Compensation for Italian Nationals Subjected to National-Socialist Measures of Persecution (Bonn, 2 June 1961), German and Italian version published in Bundesgesetzblatt II 5 July 1963 No 22, 791; Agreement between the Federal Republic of Germany and Italy on the Settlement of Certain Property-Related, Economic and Financial Questions (Bonn, 2 June 1961), German and Italian version published in Bundesgesetzblatt II 26 June 1963 No 19, 668.

${ }^{35}$ Agreement on German External Debts, 27 February 1953, UNTC No 4764 (London Debt Agreement).

${ }^{36}$ ANRP, 'Il libro bianco dell'A.N.R.P.', (2001), available at http://nnx.anrp.it/wp-content/uploads/ 2016/04/IL_LIBRO_BIANCO_dellANRP.pdf, 1-220, 85 et seq.

${ }^{37}$ Corte di Cassazione, Judgment of 21 October 2008, No 1072/2008; Corte militare d'appello di Roma, Judgment of 25 January 2008; Tribunale di Torino, Judgments of 20 May 2010 and of 20 October 2009.

${ }^{38}$ Carlo Sforza, Assemblea Costituente (31 July 1947), available at http://www.camera.it/_dati/ Costituente/Lavori/Assemblea/sed211/sed211.pdf, 6532-6566, at 6543.
} 
Nationals Subjected to National-Socialist Measures of Persecution (Agreement on Compensation) shows that the waiver of the first 1961 Agreement could not cover claims for war crimes and crimes against humanity. Both Agreements established only partial waivers. The German version of 'schwebend' and the Italian 'pendenti' referred only to claims which already made an object of specific judicial or administrative proceedings, not to claims of immaterial damages for war crimes that had yet to be prosecuted. Both lump sum Agreements were transitory, not final.

Finally, Article 3 of the Agreement on Compensation established a waiver for all claims of victims of National Socialist persecution. This concept was defined in section 1 of the German Federal Compensation Act (Bundesentschädigungsgesetz) of 1953: '[S]omeone who on grounds of political opposition to National Socialism or on grounds of race, belief or ideology was persecuted by violent National Socialist measures and thereby suffered damage to life, body, health, freedom, property, assets or in professional or economic advancement (persecutee)'. 39 Should massacres and deportation for forced labour of Italians be qualified as Nazi persecution? They were violent measures conducted by the armed forces under a German National Socialist government that ordered collective punishments for Italian political opposition to the Axis Powers. Even an element of racism might have influenced Adolf Hitler to urge for a 'tabula rasa' and a 'brutal friendship'. ${ }^{40}$ Nevertheless in the practice of compensation, the exploitation of forced labour seemed not to have been qualified per se as Nazi persecution. ${ }^{41}$ What is more, the Italian legislation reduced persecution to the repression of resistenza, adding the capture in action of rappresaglia and coercive conscription (Article 1, Decree of the President of the Republic No 2043/1963).

Germany after all has good arguments for considering the waivers of the lump sum Agreements as being all-inclusive, but the Italian interpretation of the Agreements as separate and partial waivers, excluding compensation for individual moral damages caused by war crimes, is also not straightforwardly unreasonable. German and Italian judges arrived at different conclusions, and the question was not decided by the ICJ. The way out of the deadlock could be an arbitration on the interpretation of the existing treaties as well as on the question of whether a relevant fundamental change of circumstances occurred. ${ }^{42}$

\footnotetext{
${ }^{39}$ German Federal Compensation Act (Bundesentschädigungsgesetz) of 18 September 1953, Bundesgesetzblatt I 21 September 1953 No 62, 1387.

${ }^{40}$ Frederick W Deakin, Die brutale Freundschaft: Hitler, Mussolini und der Untergang des italienischen Faschismus, (Cologne: Kiepenheuer \& Witsch 1962), 607.

${ }^{41}$ See also Stefan Kadelbach, chapter 'State Immunity, Individual Compensation for Victims of Human Rights Crimes, and Future Prospects', and Andreas von Arnauld, chapter 'Deadlocked in Dualism', in this volume.

${ }^{42} \mathrm{Cf}$ Francesco Francioni, chapter 'Overcoming the Judicial Conundrum', in this volume.
} 


\section{Fundamental Legal Changes Since 1961}

There is no doubt that some relevant changes regarding war crimes and forced labour have taken place, changes which Karl Carstens and Pio Quaroni could not have foreseen when negotiating the agreements in 1961: first, adjudication of individual compensation to victims of war crimes has become an essential part of international criminal justice, and solidarity with victims has been strengthened; second, the prohibition of forced labour as a guarantee of the dignity-related human right has become ius cogens; and third, not only has Europe witnessed German reunification but the EU itself has enlarged both its borders and core founding values, including solidarity and peace, though without a final decision on the reparations envisioned by the London Debt Agreement.

'[D]eportation to slave labour or for any other purpose of civilian population of or in occupied territory' was already punished as a war crime in the Nuremberg trials. ${ }^{43}$ British military courts exercised jurisdiction over approximately 50 German war criminals in Italy, ${ }^{44}$ and Italian courts exercised jurisdiction on a few other cases. ${ }^{45}$

Since the German Constitution of 1949 (Article 16) ruled out extradition of nationals (with exceptions admitted only in 1993), ${ }^{46}$ the issue of time limits for prosecution of Nazi crimes had already been discussed in $1960 .{ }^{47}$ The prosecution of all war crimes was guaranteed by Article 112 of the Italian Constitution, but Quaroni, a former Italian Ambassador to Moscow, was reluctant to punish Italian war crimes. ${ }^{48}$ The negotiators might have been informed that the Head of the military public prosecution office in Rome decided, on 14 January $1960,{ }^{49}$ to dismiss provisionally around 700 proceedings for German war crimes instead of starting

\footnotetext{
${ }^{43}$ See eg the cases Erhard Milch (Milch), Friedrich Flick et al (Flick), Carl Krauch et al (IG Farben), Alfried Krupp et al (Krupp). These are all cases from the Trials of War Criminals before the Nuremberg Military Tribunals. See Kevin John Heller, The Nuremberg Military Tribunals and the Origins of International Criminal Law (Oxford: OUP 2011).

${ }^{44}$ See eg the cases of Albert Kesselring, Eberhard von Mackensen and Max Simon. Cf Filippo Focardi, 'La questione dei processi ai criminali di guerra tedeschi in Italia: fra punizione frenata, insabbiamento di Stato, giustizia tardiva (1943-2005)', Storicamente 2 (2006), 1-27, at 6.

${ }^{45}$ See the cases of Herbert Kappler, Walter Reder, Wilhelm Schmalz, Joseph Strauch and Eduard Florin. Cf Marco De Paolis, 'La punizione dei crimini di guerra in Italia', in Silvia Buzzelli/Marco De Paolis/Andrea Speranzoni (eds), La ricostruzione giudiziale dei crimini nazifascisti in Italia: Questioni preliminari (Turin: Giappichelli 2012), 63-140, at 90 et seq.

${ }^{46}$ Art 26 of the Italian Constitution admitted extradition only under conditions of reciprocity.

${ }^{47}$ Deutscher Bundestag, Zur Verjährung nationalsozialistischer Verbrechen-Dokumentation der parlamentarischen Bewältigung des Problems 1960-1979 (Bonn: Deutscher Bundestag Presse- und Informationsamt 1980), et seq.

${ }^{48}$ Lutz Klinkhammer, 'La punizione dei crimini di guerra tedeschi in Italia dopo il 1945', in Gian Enrico Rusconi/Hans Woller (eds), Italia e Germania 1945-2000: la costruzione dell'Europa (Bologna: Il Mulino 2005), 75-90, at 82 et seq.

${ }^{49}$ Final report of the Italian Parliamentary Commission on the Causes of the Concealment of Records regarding Nazifascist Crime, 8 February 2006, available at http://www.camera.it/_dati/ leg14/lavori/documentiparlamentari/indiceetesti/023/018/INTERO.pdf.
} 
trials in contumaciam. The negotiators could have relied on delays and inefficiency in prosecution, but they could have not expected the establishment, several decades later, of an International Criminal Court that also adjudicates on 'reparations to, or in respect of, victims, including restitution, compensation and rehabilitation' (Article 75 of the Rome Statute, 1998). The compensation of victims includes the 'moral' damages recognized in Germany since 1970, and the 'existential damages' recognized in Italy since 2003. ${ }^{50}$ Despite persisting WWII traumas, the two states, as welfare states, learned that concrete solidarity compensation schemes for victims of war crimes were needed.

The Italian Constitution (Articles 1, 4 and 35) considers free labour as a fundamental principle of the Republic, the German Constitution (Article 12 (2-3)) prohibits forced labour, and the European Convention on Human Rights (Article 4 (3)) grants freedom from slavery. The Prohibition of Slavery and Forced Labour Convention of 1957 was ratified by Germany in 1959 and by Italy in $1968,{ }^{51}$ but the prohibition did not amount yet to ius cogens. ${ }^{52}$ The Geneva Convention of 1929 allowed forced labour of war prisoners but granted specific rights and humanitarian restrictions (Article 27-34) that need an extensive interpretation in the context of international human rights law. The Basic Principles and Guidelines on the Right to a Remedy and Reparation for Victims of Gross Violations of International Human Rights Law and Serious Violations of International Humanitarian Law adopted in 2005 recognized the 'victims' right to remedies', including equal and effective access to justice and 'adequate, effective and prompt reparation for harm suffered' 53 The German Foundation 'Remembrance, Responsibility and Future' (Erinnerung, Verantwortung und Zukunft) granted individual compensation for forced labour on the basis of a general principle of solidarity that could be transformed into a collective duty under the common constitutional law of social market economies.

Finally, a fundamental change of circumstances can be traced in the reunification of Germany and the transformations of the EU. The former Democratic Republic did

\footnotetext{
${ }^{50}$ Bundesverfassungsgericht, Order of 14 February 1973, 1 BvR 112/65, BVerfGE 34, 269 (Soraya); Corte Costituzionale, Judgment of 30 June 2003, No 233/2003.

${ }^{51}$ Germany ratified the first ILO Convention on Forced Labour of 1930 in 1956, Italy in 1934. Art 2 exempted 'any work or service exacted in cases of emergency, that is to say, in the event of war', see ILO Forced Labour Convention, 28 June 1930, in force 1 May 1932, 39 UNTS 55.

${ }^{52} \mathrm{Cf}$ ILO, 'Forced labour in Myanmar (Burma)', 2 July 1998, available at https://www.ilo.org/ public/english/standards/relm/gb/docs/gb273/myanmar.htm.

${ }^{53}$ UN General Assembly, Resolution on Basic Principles and Guidelines on the Right to a Remedy and Reparation for Victims of Gross Violations of International Human Rights Law and Serious Violations of International Humanitarian Law (16 December 2005), A/Res/60/147, paras 11, 15. See also para 20: 'Compensation should be provided for any economically assessable damage, as appropriate and proportional to the gravity of the violation and the circumstances of each case, resulting from gross violations of international human rights law and serious violations of international humanitarian law, such as: (a) Physical or mental harm; (b) Lost opportunities, including employment, education and social benefits; (c) Material damages and loss of earnings, including loss of earning potential; (d) Moral damages; (e) Costs required for legal or expert assistance, medicine and medical services, and psychological and social services.'
} 
not sign a lump sum agreement with Italy and reparation claims have never been settled. The EU treaties can be regarded as a surrogate for a peace treaty between Germany and Italy, however with notorious deficits of democratic accountability. The EU's fundamental values could suffer if both social principles (Article 23(1) of the German Constitution) and the ideal of 'justice among the Nations' (Article 11 of the Italian Constitution) are not guaranteed for the very same generations that inspired these human rights-centred foundational texts.

All these aspects are relevant to the question: is a (re)negotiation possible and desirable? However, it remains profoundly questionable whether these elements provide sufficient support for a legal claim under Article 62 of the Vienna Convention. Being such an interpretation controversial, one could argue though that engaging in good faith negotiations for a new bilateral or multilateral agreement (providing as well for an authentic interpretation and integration of the 1961 Bonn Agreements), would not be unreasonable.

\section{A Belated Solidarity}

Further objections concern time limitations for individual rights to compensation. ${ }^{54}$ Neither Italy nor Germany signed the European Convention on the Non-Applicability of Statutory Limitation to Crimes against Humanity and War Crimes of 1974. Italian judges could still align with the German position and consider that, except for genocide and murder, no international customary norm prohibits prescription of compensation claims for war crimes (Verjährung) ${ }^{55}$ The dispute regarding whether these or other limitations apply to individual compensation claims could be settled by way of arbitration or by a new decision of the ICJ. But from the point of view of the last survivors, there is no more time for further procedural delay. A 'belated solidarity' risks being rejected as 'too little too late' by those whose dignity has been violated.

At best, time might not be in Germany or Italy's favour. Any intent to gain time through further procedures would sound as much as a cynical solution, as an unhappy and anachronistic evocation of the past. Again, prudence invites us not to ignore morality in international relations, especially within the borders of supranational organizations based on common values.

The litigation on prescriptive norms, therefore, should not prevent reaching an agreement on payments due for reasons of equity. Equitable compensation could raise problems when it comes to finding political consensus, even though there would not be any question of constitutional legitimacy, since full reparation is not

\footnotetext{
${ }^{54} \mathrm{Cf}$ Giovanni Boggero/Karin Oellers-Frahm, chapter 'Between Cynicism and Idealism', in this volume.

${ }^{55}$ For the Italian case this was the position of Tribunale di Torino, Judgment of 20 October 2009, No 7137/2009.
} 
required by the Italian Constitution. To reply to the editors' questions, the German, as well as the Italian state, could honour the rights to compensation - as well as duties to social solidarity for the benefit of 'others' with the resources of a state's citizens and taxpayers - as long as these 'others' are victims of war crimes. Even if similar crimes and torts would not have been concretely assessed through judicial decisions, the rule of law of a welfare state always allows for specific forms of solidarity. The voting rights of citizens and property rights of taxpayers cannot be violated by otherwise lawful administrative or judicial decisions that fulfil a duty to international human solidarity.

It is a political question whether a similar gesture of a 'belated solidarity' would be a good investment for Germany's reputation in Europe and generally on the international plane or whether it would favour a more nationalist and populist opposition. On the one hand, there is the hope that a similar gesture could promote reconciliation, legal peace and social cohesion between Germany and Italy, while helping families to close the 'memory books'. On the other hand, there is the fear that it could become a model for other interested countries, creating a potentially dangerous and costly precedent.

The possibility of generating a consensus will depend on the specific models of organization, procedure and financing of this form of 'belated solidarity'. From the point of view of the associations of victims, Germany's pardon request for Marzabotto and the work towards a shared collective memory already represented a significant degree of compensation. The public discourses and the funding of the work of historians ${ }^{56}$ and lawyers could still be followed by the recognition of an at least symbolic economic benefits for the victims of massacres and/or forced labour. The rules for such compensation need to be construed in a way consistent with the principles of solidarity, equality and democratic responsibility; the existing national rules for solidarity with victims of violent crimes and forced labour could offer a general framework for this compensation scheme. The territorial and personal scope of this solidarity, the amount of compensation and the administrative procedure to be followed, along with the necessary funding have to be defined more in details, but some ideas could help clarify these highly complex practical problems.

\section{Territorial and Personal Scope of Solidarity}

Solidarity can be differentiated on the basis of criteria of proximity. One could argue that it should be limited to the 'former allied' countries, but over time a new proximity and ties of solidarity within the EU and within the Council of Europe (CoE) have been created. European solidarity with victims of war crimes has been strengthened through common ceremonies in and alongside war cemeteries and

\footnotetext{
${ }^{56} \mathrm{Cf}$ on the perspective of further 'prosopographic and social-statistical studies' in 'Bericht der Deutsch-Italienischen Historikerkommission’ 2012 (n 9), 169.
} 
monuments. Negotiations could start with the purpose of reaching an agreement for all victims of WWII war crimes who were citizens of the signatory states and received no compensation. War crimes, deportation, and forced labour occurred not only in Italy but elsewhere too. The United Nations War Crimes Commission (UNWCC) investigations went beyond German war crimes; citizens from Austria, Hungary, Romania, Bulgaria, and Albania, as well as 1,697 Italian citizens were among the 19,000 suspected war criminals listed. ${ }^{57}$ Massacres among civilians, for example, took place in Greece, the former Yugoslavia, and France, and not uncommonly prisoners of war from other nations, especially Poland and Russia, were the victims. These crimes as well as those committed by Allied Forces justify neither negationism nor oblivion. A bilateral or multilateral approach through a convention organized by the former Axis Powers, and perhaps open to all other states from the EU or the CoE, could be a good way for the 'bad boys' of the past to emerge as the heroes of solidarity and peace in Europe.

The right to compensation of immaterial damages deriving from war crimes could be limited to an individual una tantum to be divided among all surviving victims that have never received any compensation and who would be willing to sign an individual waiver.

Restrictions on the personal scope of the scheme in favour of living survivors needs further clarification. At current, the loss of life in wartime cannot be individually compensated. As Jochen Frowein correctly argued in a hearing of the Bundestag in 2015, recognising the suffering of surviving victims does not require an extension of the benefits to the surviving relatives of deceased victims. ${ }^{58} \mathrm{~A}$ 'belated solidarity' would be de facto a restricted one, but could be justified on a 'better late than never' basis. Nevertheless, in order to prevent any cynical interest in lengthy negotiations so as to possibly mitigate the financial impact of the new compensation/reparation regime, it would not be unreasonable to accept an extension so as to include the families of victims who had survived until the date of the ICJ Judgment. On the other hand, surviving victims of war crimes committed by Italian forces could not be a priori excluded.

\section{Calculation of the Reparation}

The amount could be calculated on the basis of the average compensation recognized by national administrations or courts or by the International Criminal Court, adapted

\footnotetext{
${ }^{57} \mathrm{Cf}$ the proceedings of the United Nations War Crimes Commission (UNWCC), 1943-1949.

${ }^{58}$ Jochen A Frowein, 'Stellungnahme zu den Anträgen auf symbolische Entschädigung noch lebender sowjetischer Kriegsgefangener' (13 May 2015), available at www.bundestag.de/blob/ 374858/d050da4429429f261745a4e37c1970ca/prof\%2D\%2Ddr\%2D\%2Djochen-a\%2D\% 2Dfrowein-data.pdf.
} 
to the average income of the country where the victim is living and according to a projection of the number of beneficiaries.

The case of the Italian victims of forced labour is a special one, in reason of their exclusion from the schemes of the German Foundation 'Remembrance, Responsibility and Future' (Erinnerung, Verantwortung und Zukunft). ${ }^{59}$ The proposals regarding Russian military internees and war prisoners presented in 2015 by the two then opposition parties in the German Bundestag ${ }^{60}$ proposed $€ 2,500$ (Grüne) or $€ 7,670$ (Die Linke) for each victim. The smaller sum is based on the 'recognition payment for former German forced labour workers' granted by a directive of the German Ministry of the Interior of 7 July 2016. The larger amount is equal to the payments for forced labour granted by the Foundation 'Remembrance, Responsibility and Future'. Even without any specific law or constitutional obligation, the German state, through this financial instrument, paid tribute to the hard 'destiny' of German citizens and people that carried out forced labour for a foreign power. This is an important but ambiguous precedent. It could be a model of humble and noble human solidarity, but it could also be based on a limited ideal of solidarity, since restricted exclusively to German nationals.

Another alternative or cumulative form of solidarity could be the establishment of a solidarity fund for charitable subsidies to all those victims who did not get a sufficient pension treatment or who are still suffering diseases caused by war crimes and torts in question. Even aids for concrete reconciliation initiatives in Germany and Italy (for example travel reimbursements) could be offered by this 'belated solidarity' fund.

All these benefits would need to be investigated, but no judicial decision would be required for recognising the status of the victims of crimes and forced labour. The benefits could be granted through a specific administrative procedure by national administrations under the directives and control of a common international board. ${ }^{61}$

\section{Financing}

The main question is how to finance the different forms of solidarity and financial recognition. All possible sources of solidarity funding should be considered, including private donations and contributions from all those that benefitted from forced labour, as well as military related industries and railway enterprises. Similar donations could be eligible for tax benefits. State contributions to this fund could be

\footnotetext{
${ }^{59}$ It is worth noting that the German scheme influenced also the Austrian Fund 'Reconciliation, Peace and Cooperation' (Reconciliation Fund).

${ }^{60}$ See Deutscher Bundestag, 'Plädoyer für Entschädigungen' (19 May 2015), available at www. bundestag.de/presse/hib/2015_05/-/375140.

${ }^{61}$ Cf Filippo Fontanelli, chapter 'Sketches for a Reparation Scheme', in this volume.
} 
calculated on an equal basis for each state on a personal per capita solidarity basis (specifying an amount for each citizen from the respective signatory states).

Italian participation would strengthen the principle of common European solidarity. Of course, Germany could ask the ICJ for an 'equitable satisfaction' to be granted in an analogous application of Article 30 of the European Convention on Dispute Settlement, and this satisfaction if granted might be allocated for funding. Alternatively, Italy could participate spontaneously, in part due to the force of its fundamental constitutional principle of solidarity which authorizes the Republic to concur even in international solidarity funds. The exclusion from the existing compensation schemes of victims of massacres and forced labour was a common decision of both the German and the Italian governments and common funding would therefore be the best way to render a 'belated solidarity' viable. ${ }^{62}$

Another exclusively political question is whether a similar project of 'belated solidarity' would be rejected by a majority of taxpayers who might be no longer willing to pay for past wrongdoings or to subscribe to forms of 'chequebook-baseddiplomacy'. The 'bottomless-pit' argument is always an equity blocker, but a now reunified Germany should not forget that the Two Plus Four Treaty ${ }^{63}$ was not the final peace treaty envisaged by the London Debt Agreement and that a consolidation of the lump sum agreements could be the best way to provide an acceptable monetary limit.

\section{The Proper Use of Supreme Principles as Part of the 'Constitutional Identity'}

The binational discussion on an equitable solution would likely not end the debate over the question of remedies against immunity. We are moving from a traditional dualist approach, as the likes of Dionisio Anzilotti and Heinrich Triepel, towards neither an international nor a national monism but towards a more recent pluralist approach. ${ }^{64}$ A way out of the deadlock might lay in searching for procedures that could help finding ad hoc balances, while avoiding clashes between the two parties involved. This should be done through concrete forms of communication between the diverging legal orders and cultures rather than through an a priori hierarchy between supreme constitutional principles of rights protection and sovereign immunity.

\footnotetext{
${ }^{62}$ See also Francesco Francioni, chapter 'Overcoming the Judicial Conundrum', in this volume.

${ }^{63}$ Treaty on the Final Settlement with Respect to Germany, 12 September 1990, 1696 UNTS 115 (Two-Plus-Four Treaty).

${ }^{64}$ As favoured by Anne Peters, 'Let Not Triepel Triumph: How to Make the Best Out of Sentenza No. 238 of the Italian Constitutional Court for a Global Legal Order', EJIL: Talk! (26 December 2014), available at www.ejiltalk.org/let-not-triepel-triumph-how-to-make-the-best-out-of-sentenzano-238-of-the-italian-constitutional-court-for-a-global-legal-order-part-i/.
} 
The ItCC's Sentenza 238/2014 did not use the concept of constitutional identity quoted by the Tribunal of Florence and which is not yet well established in the ItCC's jurisprudence. ${ }^{65}$ The Court preferred to invoke 'the fundamental principles of the constitutional order and inalienable human rights', which is a mix of principles that can serve for a coordination of the values of constitutionalism and international rule of law.

In the interlocutory Taricco case, a new complex case of prima facie conflict between the rule of law at the national and international level, the ItCC used the concept of constitutional identity only in the context of EU law: ${ }^{66}$ 'This Court would like to stress that, whilst the aim of the interpretation set out above is to preserve the constitutional identity of the Republic of Italy, it does not however compromise the requirements of uniform application of EU law and is thus a solution that complies with the principle of loyal cooperation and proportionality. ${ }^{67}$ The use of the concept of constitutional identity was based on a specific national tradition and constitutional culture, aimed at giving a higher protection to the citizens' legal certainty than to the state (or EU) interests.

A similar solution, encouraging a harmonized interpretation of the different legal systems, was unworkable for the ICJ Judgment because there were, and still there are, no specific forms of dialogue between the ICJ and national constitutional courts. ${ }^{68}$ The ItCC attempted to qualify the right of access to justice in cases of serious violations of fundamental rights also as an international rule of law principle to be taken seriously by all international and municipal judges. This interpretation is based on a supreme principle of the Italian Constitution (Article 2) which should be respected at least as a domestic exception to the rule of state immunity. Now, one could read Sentenza 238/2014 as a plea for tolerance and respect for a supreme constitutional principle. The Judgment outlines a distinctive Italian constitutional

\footnotetext{
${ }^{65}$ Corte Costituzionale, Judgment of 19 March 2001, No 73/2001: '[T]his Court—as the referring judge recalls-reaffirmed the principle that the tendency of the Italian legal order to be open to generally recognized norms of international law and international treaties is limited by the necessity to preserve its identity; thus, first of all, by the values enshrined in the Constitution'. In Corte Costituzionale, Judgment of 7 October 2009, No 262/2009, the concept is still synonymous with the whole constitutional design and system of equality and immunities. Cf Michel Rosenfeld, 'Constitutional Identity', in Michel Rosenfeld/András Sajó (eds), The Oxford Handbook of Constitutional Comparative Law (Oxford: OUP 2012).

${ }^{66}$ Corte Costituzionale, Order of 23 November 2016, No 24/2017: 'Naturally, the Court of Justice is not exempt from the task of defining the scope of EU law and cannot be further encumbered by the requirement of assessing in detail whether it is compatible with the constitutional identity of each Member State. It is therefore reasonable to expect that, in cases in which such an assessment is not immediately apparent, the European court will establish the meaning of EU law, whilst leaving to the national authorities the ultimate assessment concerning compliance with the supreme principles of the national order.'

${ }^{67}$ Ibid: 'The Italian Constitution construes the principle of legality in criminal matters more broadly than European law as it does not limit itself to describing the conduct constituting the offence and the penalty, but rather covers all substantive aspects of liability to punishment.'

${ }^{68}$ See also Alessandro Bufalini, chapter 'Waiting for Negotiations', in this volume.
} 
identity in the international legal order, representing as well a leading case for a moderate use of the concept of constitutional identity itself. ${ }^{69}$

On the other side and in more general terms, the invocation of a constitutional identity could also be understood as a 'trump card' that weakens international customary law and the authority of international judges, and further backs a new nationalist monism. From this more sceptical point of view, the constitutional identity exception could promote a national-constitutional-rights fundamentalism and enhance the power of domestic judges. While the first interpretation, influenced by an idealism based on tolerance, could strengthen the international rule of law; the second interpretation, inspired by legal realism, could instead promote its decline. ${ }^{70}$

The first, 'tolerant' reading could be more consistent with the Italian Constitution, but constitutional justices should acknowledge that constitutional identity includes a fundamental principle of 'internationality'. Among 'fundamental principles', the first part of the Italian Constitution recognizes the primacy of general rules of international customary law (Article 10(1)), the right of asylum of any 'foreigner who (...) is denied the actual exercise of the democratic freedoms' (Article 10(3)), the 'repudiation' of war as an instrument of aggression against the freedoms of other peoples, as well as a favour for limitations of sovereignty that 'may be necessary to a world order ensuring peace and justice among the Nations' (Article 11). These principles already moderate dualist readings and offer together with the other commitments - the protection of democracy (Article 1), human rights (Article 2), equality (Article 3), labour (Article 4), local autonomies (Article 5), linguistic minorities (Article 6), religious peace (Article 7 and 8), cultural development (Article 9)-substantial elements to an international constitutionalism, a design for a future constitution in a world governed by common principles. ${ }^{71}$ Taking these fundamental constitutional principles and human rights seriously in a pluralist perspective, the ItCC would act not only as an organ of the national constitutional state but of the international community.

The question of constitutional identity is not just about who and what we are; it deals first of all with how we interact with others. Therefore, the new tool of constitutional identity needs to be embedded in good procedures. Domestic ordinary judges, as well as constitutional and EU judges are still learning how to conduct a dialogue around identity questions, but even without preliminary question mechanisms some instruments of indirect dialogue with the ICJ could be developed.

The rules of the ICJ allow, if necessary, to arrange for an enquiry or an expert opinion (Article 67 ICJ Statute) on questions related to the respect of national 'constitutional identities' relevant for controversies on international customary

\footnotetext{
${ }^{69} \mathrm{Cf}$ Antonio Ruggeri, 'Conflitti tra norme internazionali consuetudinarie e Costituzione, atto secondo: quali i possibili “seguiti” della 238 del 2014?', Consulta Online, (5 March 2015), available at http://www.giurcost.org/studi/ruggeri45.pdf, 34-59.

${ }^{70}$ Heike Krieger/Georg Nolte, 'The International Rule of Law-Rise or Decline?-Points of Departure', KFG Working Paper Series 1 (2016), 1-23.

${ }^{71}$ Jan Klabbers/Anne Peters/Geir Ulfstein (eds), The Constitutionalization of International Law, expanded edition 2011 (Oxford: OUP 2009).
} 
law. The ICJ 'may request of public international organizations information relevant to cases before it, and shall receive such information presented by such organizations on their own initiative' (Article 34 ICJ Statute). Expert opinion as well as information procedures could involve the Venice Commission and the World Conference on Constitutional Justice. The same instruments could be used by national constitutional judges when facing potential conflicts between constitutional identity and international customary law.

In the Italian system of constitutional justice, there is no specific judicial procedure for scrutinizing whether a national legal Act is compatible with international law (such as the 'Normenverifikation' under Article 100(2) of the German Constitution). The ItCC could be asked whether an Italian legislative Act is compatible with a norm of international customary law and could then decide incidenter tantum that the customary norm is compatible with the supreme principles of constitutional identity. Furthermore, Sentenza 238/2014 created a new type of proceeding on the basis of an analogy: the other judges can refer incidenter tantum to the ItCC the question on whether or not a norm of international customary law they have to apply is compatible with the Italian constitutional identity. ${ }^{72}$

In this regard, the constitutional identity review could require specific rules made by the legislator through constitutional amendments (Article 137 of the Italian Constitution). The constitutional lawmakers could decide whether the right use of constitutional identity to international customary law implies a power to deliberately 'nullify' international judgments and the rules that govern their execution. If the constitutional judges have the power to decide that an international customary norm contrary to constitutional identity is null and void, also the European constitutional review over legislative Acts risks being transformed into the power to annul international judgments. The best way to avoid an ultra vires exception against Sentenza $238 / 2014$ could be a codification of this new self-made proceeding of constitutional justice.

Finally, the right use of constitutional identity should always require the highest possible standard of argumentation and hermeneutics. When constitutional rights and their limitations are invoked in the name of constitutional identity, ponderation even between the supreme principles has to be enhanced. The right to remedies can prevail at the national level and the privileges of state immunities at the international level, but under conditions of pluralism, ponderation in the relationship between the rule and exception is not established once and for all.

A world where the harshest forms of injustice cannot be addressed and access to justice is recognized to Arnold the Miller ${ }^{73}$ but not to a forced labourer or to a victim of war crimes would disregard its own minima moralia. Yet, a world where access to

\footnotetext{
${ }^{72}$ Following Corte Costituzionale, Order of 11 February 2015, No 30/2015, the Court had decided the 'inexistence ( $a b$ origine)' of the state immunity norm insofar as it was conflicting with a fundamental constitutional principle.

${ }^{73}$ The anecdote of the miller of Potsdam (the Miller-Arnold-Case) is famously described in Thomas Carlyle, 'History of Friedrich II of Prussia', Vol 21, The Works of Thomas Carlyle, Vol 3, (Cambridge: CUP 2010) 243 et seq.
} 
justice is used for the self-empowerment of judges to compel governments into negotiations would lead to a reality in which fiat iustitia, et pereat mundus.

If one looks at the general usage in biology, 'immunity' means the capability of multicellular organisms to resist the entrance of harmful microorganisms. ${ }^{74}$ Applied in different biological, technical and legal contexts, immunity depicts the body of a person or an organization with a life and a constitutional equilibrium. Subjective rights defended in courts can be aggressive and harmful to the whole, but they can include claims for immunities, for example the claim of soldiers to be protected by an adequate umbrella of state immunity. In its Roman law origin, immunity did not refer to the state but to the freedom of a citizen from public duties and, especially, taxes. Immunity was the opposite of community - both deriving from munus - and the idea is still that any excessive immunization could transform a protection of life into its negation. ${ }^{75}$

The balancing between remedies and immunity needs to be handled by governments alongside judges, taking into account the specific European context. More than sixty years after the signature of the first treaties, the permanent dialogue between Germany and Italy has a difficult future. ${ }^{76}$

The traumas of WWII persist. The facts at the origin of the remedies $v$ immunity controversy constitute a living history that is still awaiting a commonly agreed conclusion.

\section{References}

Allain, Jean, Slavery in International Law-Of Human Exploitation and Trafficking (Leiden: Brill, Nijhoff 2012)

Dal Canto, Francesco, Il giudicato costituzionale nel giudizio sulle leggi (Turin: Giappichelli 2002)

Deakin, Frederick W, Die brutale Freundschaft: Hitler, Mussolini und der Untergang des italienischen Faschismus (Cologne: Kiepenheuer \& Witsch 1962)

De Paolis, Marco, 'La punizione dei crimini di guerra in Italia', in Silvia Buzzelli/Marco De Paolis/ Andrea Speranzoni (eds), La ricostruzione giudiziale dei crimini nazifascisti in Italia: Questioni preliminari (Turin: Giappichelli 2012), 63-140

Esposito, Roberto, Immunitas: The Protection and Negation of Life (London: Polity Press 2011)

Focardi, Filippo, 'La questione dei processi ai criminali di guerra tedeschi in Italia: fra punizione frenata, insabbiamento di Stato, giustizia tardiva (1943- 2005)', Storicamente 2 (2006), 1-27

\footnotetext{
${ }^{74}$ See, eg, Reece Davis, Cellular and Molecular Immunology (Waltham Abbey: ED-Tech Press 2019), at 36.

${ }^{75}$ Roberto Esposito, Immunitas: The Protection and Negation of Life (London: Polity Press 2011).

${ }^{76}$ Both states should not be blind to the past, including the darker legacy of the 'establishment of a new order in Europe' envisaged in the tripartite pact of 27 September 1940. From a legal point of view, Germany invaded Italy-in a clear violation of the Briand-Kellogg Pact of 1928. The alleged violation of the obligation of military defence in the tripartite pact could not justify German aggression, answered as it was by the Italian declaration of war of 17 October 1943. This fatal mistake could be recognized in a formal public statement with which Germany assumes its responsibility.
} 
Frowein, Jochen A, 'Stellungnahme zu den Anträgen auf symbolische Entschädigung noch lebender sowjetischer Kriegsgefangener' (13 May 2015), available at www.bundestag.de/ blob/374858/d050da4429429f261745a4e37c1970ca/prof\%2D\%2Ddr\%2D\%2Djochen-a\%2D $\% 2$ Dfrowein-data.pdf

Heller, Kevin John, The Nuremberg Military Tribunals and the Origins of International Criminal Law (Oxford: OUP 2011)

Herbert, Ulrich, Hitler's Foreign Workers: Enforced Labor in Germany under the Third Reich (Cambridge: CUP 1997)

Klabbers, Jan/Anne Peters/Geir Ulfstein (eds), The Constitutionalization of International Law, expanded edition 2011 (Oxford: OUP 2009)

Klinkhammer, Lutz, 'La punizione dei crimini di Guerra tedeschi in Italia dopo il 1945', in Gian Enrico Rusconi/Hans Woller (eds), Italia e Germania 1945-2000: la costruzione dell'Europa (Bologna: Il Mulino 2005), 75-90

Krieger, Heike/Georg Nolte, 'The International Rule of Law-Rise or Decline?-Points of Departure', KFG Working Paper Series 1 (2016), 1-23

Kuby, Erich, Verrat auf Deutsch-Wie das Dritte Reich Italien ruinierte (Frankfurt: Ullstein Sachbuch 1987)

Peters, Anne, 'Let Not Triepel Triumph: How to Make the Best Out of Sentenza No. 238 of the Italian Constitutional Court for a Global Legal Order', EJIL: Talk! (26 December 2014), available at www.ejiltalk.org/let-not-triepel-triumph-how-to-make-the-best-out-of-sentenzano-238-of-the-italian-constitutional-court-for-a-global-legal-order-part-i/

Rinke, Stefan, Schadensersatzklagen gegen Staaten wegen schwerer Menschenrechtsverletzungen im europäischen Zivilprozessrecht (Berlin: Berliner Wissenschafts-Verlag 2017)

Rosenfeld, Michel, 'Constitutional Identity', in Michel Rosenfeld/András Sajó (eds), The Oxford Handbook of Constitutional Comparative Law (Oxford: OUP 2012)

Ruggeri, Antonio, 'Conflitti tra norme internazionali consuetudinarie e Costituzione, atto secondo: quali i possibili “seguiti” della 238 del 2014?', Consulta Online, (5 March 2015), available at http://www.giurcost.org/studi/ruggeri45.pdf, 34-59

Tomuschat, Christian, 'Leistungsberechtigung der Italienischen Militärinternierten nach dem Gesetz zur Errichtung einer Stiftung "Erinnerung, Verantwortung und Zukunft"?Rechtsgutachten' (2001), available at http://www.berliner-geschichtswerkstatt.de/ zwangsarbeit/imi/imi-tomuschat-gutachten.pdf, 1-37

Veronesi, Paolo, Colpe di stato (Milan: Franco Angeli 2017)

Open Access This chapter is licensed under the terms of the Creative Commons Attribution 4.0 International License (http://creativecommons.org/licenses/by/4.0/), which permits use, sharing, adaptation, distribution and reproduction in any medium or format, as long as you give appropriate credit to the original author(s) and the source, provide a link to the Creative Commons license and indicate if changes were made.

The images or other third party material in this chapter are included in the chapter's Creative Commons license, unless indicated otherwise in a credit line to the material. If material is not included in the chapter's Creative Commons license and your intended use is not permitted by statutory regulation or exceeds the permitted use, you will need to obtain permission directly from the copyright holder.

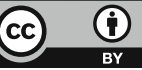

